\title{
PERSONALIZED MEDICINE FOR EFFECTIVE TREATMENT OF NON- SMALL-CELL LUNG CANCER WITH TARGETED THERAPIES
}

\author{
Duong Hong Quan \\ Laboratory Center, Hanoi University of Public Health, Hanoi, Vietnam \\ Received 10 March 2020, accepted 10 August 2020
}

\begin{abstract}
Lung cancer is the most common cause of cancer death worldwide, with most deaths having distant metastases. It has become increasingly complex to get effective treatment for lung cancer patients. While generalized medicine with traditional therapy resulted in comparatively poor response, personalized medicine has been well known to be an important strategy for effective treatment of lung cancer, with current focus on significant detection of clinical oncogenic drivers responsible for tumor initiation and maintenance and development of drug resistance. In lung cancer, especially in non-small-cell lung cancer (NSCLC), EGFR, ALK, RET, ROS1, BRAF, KRAS, NRAS, PIK3CA, DDR2, MET, ERBB2 have been reported to be key oncogenic drivers, which are targeted in the development and application of targeted therapeutic drugs. Personalized medicine based on these oncogenic drivers is highly recommended for treatment of advanced NSCLC patients. In this article, the significant application of personalized medicine based on the key oncogenic drivers for effective treatment of NSCLC with targeted therapeutic drugs is reviewed.
\end{abstract}

Keywords: Personalized medicine, targeted therapy, non-small-cell lung cancer, treatment.

Citation: Duong Hong Quan, 2020. Personalized medicine for effective treatment of non-small-cell lung cancer with targeted therapies. Academia Journal of Biology, 42(3): 119-133. https://doi.org/10.15625/2615-9023/v42n3.14883.

Corresponding author email: dhq@huph.edu.vn

(C2020 Vietnam Academy of Science and Technology (VAST) 


\section{INTRODUCTION}

Lung cancer is the most frequently diagnosed human malignant tumor and remains the highest cancer-related cause of mortality in both sexes with approximately 2.1 million newly diagnosed cancer cases and 1.8 million cancer related-deaths each year worldwide (Bray et al., 2018). In 2018, there were 23667 newly diagnosed cases and 20710 deaths from this cancer in Vietnam. Despite significant advances made in both diagnostic and treatment approaches in recent years, the average 5 years survival rate remains at only $16 \%$ because the diagnosis is only conducted at advanced stages and consequently, patients have a very poor prognosis (Bray et al., 2015; Gridelli et al., 2015). Based on histopathological features, non-small-cell lung cancer (NSCLC) and small cell lung cancer (SCLC) accounts for $85 \%$ and $15 \%$ of all patients with lung cancer, respectively (Travis et al., 2013). NSCLC is divided into subtypes, being adenocarcinoma (ADC) and squamous cell carcinoma (SCC) (Travis et al., 2013). Furthermore, ADC represents $50 \%$ of cases among all lung cancer subtypes (Travis et al., 2013).

Personalized medicine, as defined by the National Cancer Institute (NCI), is a form of medicine using personal information about genes, proteins and environments for prevention, diagnosis and treatment of disease. Therefore, personalized medicine for NSCLC takes into consideration specific characteristics of each patient's tumor to prescribe the most effective approach for treatment. Especially, there has been a major change in the empirical treatment of NSCLC from using one drug for all to a targeted therapy by using the most effective drug for each patient (Li et al., 2013; Reungwetwattana \& Dy, 2013). Furthermore, most advances in treatment using targeted therapy in NSCLC occurred in ADC due to the identification of targetable mutations being more common than in SCC. In NSCLC, personalized medicine based on targetable profiles of tumor such as EGFR (EGFR mutation, 20-30\%), ALK (ALK rearrangement, 1-10\%), RET (RET rearrangement, 1-2\%),
ROS1 (ROS1 rearrangement, 1-2\%), BRAF (BRAF mutation, 2-5\%), KRAS (KRAS mutations, 32\%), NRAS (NRAS mutation, 2-3\%), PIK3CA (PI3KCA mutation, 5-6\%), DDR2 (DDR2 mutation, 4\%), MET (MET exon 14 skipping, 1-3\%) and ERBB2 (ERBB2 amplication, $1-3 \%$ and ERBB2 mutation, 2-4\%) have been identified for effective treatment of NSCLC patients (Sharma et al., 2007; Suh et al., 2016; Rosas et al., 2019; Du et al., 2018; Bergethon et al., 2012; Lin, Shaw, 2017; Takeuchi et al., 2012; Farago, Azzoli, 2017; Guo et al., 2019; O'Leary et al., 2019; Aviel-Ronen et al., 2006; Vuong et al., 2018; Li et al., 2016).

Personalized medicine has been considered and integrated as a routine best practice for NSCLC patients with advanced stage from the year 2000 (Pfister et al., 2004). Then, to better understand the significant role of personalized medicine in NSCLC, this review summarizes the current personalized medicine strategies for effective treatment of NSCLC patients.

\section{PERSONALIZED MEDICINE BASED ON TARGETABLE PROFILE OF TUMOR}

\section{EGFR mutation}

EGFR, a transmembrane receptor protein with tyrosine kinase activity, has been well known to be involved in the pathogenesis of various types of cancer including NSCLC. Therefore, EGFR is the most attractive target for development of targeted therapy to treat cancer. The EGFR mutation, found in $20-30 \%$ of NSCLC with adenocarcinoma, showed potential for targeted therapies in clinical trials for the treatment of NSCLC (Sharma et al., 2007; Suh et al., 2016). The $E G F R$ mutation is more prevalent in nonsmokers and in the Asian population (Sharma et al., 2007; Shi et al., 2014).

Exon 19 deletion, exon 19 insertion, exon 20 insertion and missense mutation are four main types of EGFR mutations (Sharma et al., 2007). Of these, two most common mutation contents of EGFR, being exon 19 deletion (delE746-A750) and exon 21 missense mutation (L858R), are found in $90 \%$ of $E G F R$ 
mutations in NSCLC patients with adenocarcinoma. The second most common mutations of EGFR are frame deletion in exon 19 or point mutations in exon 18 and exon 21 . The third most common mutation of EGFR is exon 20 insertion (Sharma et al., 2007).

Targeted therapeutic drugs have been used for effective treatment of NSCLC patients with indicated EGFR mutation (Table 1). However, all NSCLC patients harboring EGFR mutation will eventually become resistant to Erlotinib and Gefitinib (first-generation EGFR inhibitors). Acquired resistance due to the T790M mutation in exon 20 of EGFR is detected in $50-60 \%$ of cases with secondary resistance to first-generation EGFR inhibitors (Chong \& Jänne, 2013). Afatinib and Dacomitinib (second-generation EGFR inhibitors) have been developed for such cases (Li et al., 2008). However, NSCLC patients with T790M would also develop resistance to Afatinib. Osimertinib, a third-generation EGFR inhibitor developed to treat NSCLC patients previously treated with Afatinib, is now approved by FDA, and recommended for treatment of EGFR T790M positive NSCLC patients (Mok et al., 2017).

\section{ALK rearrangement and/or mutation}

ALK, a transmembrane tyrosine kinase receptor, was identified specifically in NSCLC (Rikova et al., 2007). Rearrangement, point mutation and amplification are three types of oncogenesis in $A L K$.

ALK rearrangement, identified in approximately $1-10 \%$ of NSCLC patients, could benefit from targeted therapies for the treatment of NSCLC (Rosas et al., 2019; Du et al., 2018). To date, in NSCLC, 20 distinct ALK rearrangements have been detected, among which 11 are oncogenetic drivers, being EML4-ALK, KIF5B-ALK, KLC1ALK, HIP1-ALK, BIRC6-ALK, PRKAR1AALK, PPM1B-ALK, EIF2AK3-ALK, BCL11A-ALK, CEBPZ-ALK and PICAMALK (Rosas et al., 2019; Du et al., 2018). Among these oncogenetic drivers, EML4ALK, found in approximately $3-13 \%$ of all ALK arrangements, occurs most frequently in
NSCLC (Inamura et al., 2008; Shaw et al., 2009; Sun et al., 2010; Horn \& Pao, 2009; Du et al., 2018). ALK rearrangements are especially more common in younger adenocarcinoma patients who are nonsmokers or light smokers (Camidge et al., 2010; Shaw et al., 2009). Targeted therapeutic drugs such as Crizotinib (first-generation inhibitor of ALK and MET), Ceritinib (second-generation inhibitor of ALK), Alectinib (inhibitor of ALK), Brigatinib (third-generation inhibitor of ALK and EGFR), and Lorlatinib (third-generation inhibitor of ALK and ROS1) have been used for the effective treatment of NSCLC patients with indicated ALK rearrangement and/or mutation (Table 1).

Another main type of oncogenesis in $A L K$ is point mutation. Acquired resistance due to secondary mutations of $A L K$ in NSCLC patients with ALK rearrangement treated with Crizotinib, are caused by mutations in the target $A L K$ gene (Toyokawa \& Seto, 2015; Lin et al., 2017). The secondary mutations of ALK, causing acquired resistance to ALK inhibitor such as Crizotinib, are 1151Tins, L1152R, C1156Y, F1174L, L1196M, L1198F, G1202R, S1206Y, G1269A, I1171T, D1203N and V1180L (Lin et al., 2017; Du et al., 2018). To treat effectively for NSCLC patients with ALK rearrangement previously treated with Crizotinib, Alectinib and Ceritinib have been developed (Shaw et al., 2014; Shaw et al., 2016). Afterwards, NSCLC patients with ALK rearrangement also develop resistance to Alectinib and/or Ceritinib due to new mutations in $A L K$ such as as G1202R, for which Lorlatinib has been developed (Katayama, 2017).

\section{ROS1 rearrangement}

Rearrangement of ROS1, a receptor of the insulin receptor family with constitutive kinase activity, were found in NSCLC in 2007 (Rikova et al., 2007). ROS1 rearrangement, identified in $1-2 \%$ of NSCLC, could benefit from targeted therapies (Bergethon et al., 2012; Lin, Shaw, 2017). To date, 14 distinct ROS1 rearrangement have been detected in NSCLC, being CD74-ROS1, SDC4-ROS1, 
SLC34A2-ROS1, EZR-ROS1, TPM3-ROS1, LRIG3-ROS1, FIG-ROS1, KDELR2-ROS1, CCDC6-ROS1, MSN-ROS1, TMEM106BROS1, TPD52L1-ROS1, CLTC-ROS1 and LIMA-ROS1 (Lin, Shaw, 2017). Among these contents of ROS1 rearrangements, CD74ROS1 occurs most frequently in NSCLC (Gainor, Shaw, 2013). Crizotinib (inhibitor of ALK and MET) has been used for the effective treatment of NSCLC patients with indicated the ROS1 rearrangements (Table 1).

\section{RET rearrangement}

Rearrangement in RET, a proto-oncogene, were identified to be the result of transfection of the NIH3T3 cells with high molecular weight DNA of a human T-cell lymphoma (Takahashi et al., 1985). RET rearrangements found in 1-2\% of NSCLC cases, could benefit from targeted therapies (Takeuchi et al., 2012; Farago, Azzoli, 2017). To date, the RET rearrangement detected in NSCLC are KIF5B-RET, CCDC6-RET, NCOA4-RET, EPH5-RET and PICALM-RET (Takeuchi et al., 2012; Farago, Azzoli, 2017). Among these, KIF5B-RET is the most common RET rearrangement in NSCLC (72\%) (Takeuchi et al., 2012; Kohno et al., 2012; Farago, Azzoli, 2017). Targeted therapeutic drugs such as Cabozantinib (a multikinase inhibitor active against VEGFR2, MET, ROS1, AXL, KIT, TIE2 and RET), and Vandetanib (a multikinase inhibitor active against VEGFRs, EGFR, and RET) have been used for the effective treatment of NSCLC patients with indicated RET rearrangement (Table 1).

\section{BRAF mutation}

BRAF, an intracellular serine/threonine kinase, activates the MAPK signaling pathway to regulate cell growth and proliferation. $B R A F$ mutations, found in $2-5 \%$ of NSCLC cases, could benefit from targeted therapies (Suh et al., 2016; Guo et al., 2019; O'Leary et al., 2019). For NSCLC, missense mutation of $B R A F$, classified into V600E (90\%) and nonV600E (G469L and Y472C) subtypes, mainly in current and former smokers (Marchetti et al., 2011; Cardarella et al., 2013). Especially, all NSCLC patients with the non-V600E subtypes are heavy smokers (Cardarella et al., 2013). Dabrafenib and/or Vemurafenib (BRAF inhibitor) have been used for the effective treatment of these NSCLC patients with indicated BRAF mutations (Table 1).

\section{KRAS mutation}

KRAS, a member of the RAS family, activates the RAF/MAPK and PI3K signaling pathway to control cell growth and proliferation. KRAS mutations, found in up to $32 \%$ of NSCLC cases, could benefit from targeted therapies (Aviel-Ronen et al., 2006; Suh et al., 2016; Guo et al., 2019). In NSCLC the most common mutations of KRAS at codon 12 are G12C (43\%), G12V (18\%) and G12D (11\%). Especially, KRAS mutation is predominantly associated with NSCLC patients who have adenocarcinoma and are non-Asian smokers (Aviel-Ronen et al., 2006). Targeted therapeutic drug such as Trametinib (MEK1/2 inhibitor) has been used for the effective treatment of NSCLC patients with indicated KRAS mutations (Table 1).

Furthermore, in NSCLC, KRAS mutations are well known as non-druggable targets that predict resistance to EGFR inhibitors such as Erlotinib and Gefitinib (Chong, Jänne, 2013) and to ALK inhibitors such as Crizotinib (Gainor et al., 2013), i.e. KRAS mutations are mutually exclusive with EGFR mutations and ALK rearrangements in NSCLC (Chong, Jänne, 2013; Gainor et al., 2013).

\section{NRAS mutation}

NRAS, a member of RAS family and a GTPase related to KRAS, regulates cell growth, proliferation and differentiation. NRAS mutations, identified in approximately $2-3 \%$ of NSCLC case, could benefit from targeted therapies (Suh et al., 2016). NRAS mutations are more common in NSCLC patients being current/former smokers (Ohashi et al., 2013). Trametinib (MEK1/2 inhibitor) has been used for effective treatment of NSCLC patients with indicated NRAS mutations (Table 1).

\section{PI3KCA mutation}

PI3KCA, a catalytic subunit of the class IA PI3K which is the member of a family of 
heterodimeric kinases, plays an important role in the regulation of cell growth, survival and motility. PI3KCA amplification and mutation are two main types of aberrant activation of PI3K. Among them, PI3KCA mutations, found in approximately 5-6\% of NSCLC patients, could benefit from targeted therapies (Suh et al., 2016; Guo et al., 2019). targeted therapeutic drugs such as Erlotinib and/or Gefitinib (EGFR inhibitor) have been used for the effective treatment of NSCLC patients with indicated PI3KCA mutation (Table 1).

\section{DDR2 mutation}

DDR2, a receptor tyrosine kinase binding collagen I and III as its endogenous ligand, promotes cell proliferation, migration and metastasis by regulation of EMT (Vogel et al., 1997; Labrador et al., 2001; Walsh et al., 2011). DDR2 mutations, found in approximately $4 \%$ of NSCLC cases, could benefit from targeted therapies (Suh et al., 2016; Guo et al., 2019). Only one targeted therapeutic drug, Dasatinib (SRC inhibitor), has been used for the effective treatment of NSCLC patients with indicated DDR2 mutation (Table 1).

\section{MET mutation}

MET, a transmembrane receptor tyrosine kinase, plays an important function in embryogenesis, tumor growth and metastasis. Amplification, activating point mutation and $M E T$ exon 14 skipping are three main types of $M E T$ gene alteration. Among them, MET exon 14 skipping, reported in approximately 1-3\% of NSCLC patients, could benefit from targeted therapies (Suh et al., 2016; Vuong et al., 2018). Targeted therapeutic drugs such as Crizotinib (inhibitor of MET and ALK), Capmatinib (MET inhibitor) and/or Glesatinib (inhibitor of MET and AXL) have been used for the effective treatment of NSCLC patients with indicated mutations in MET exon 14 skipping (Table 1).

\section{ERBB2 mutation}

ERBB2, a member of the ERBB family, activates downstream signaling pathway to drive oncogenesis in several types of cancer including lung cancer when forming with other members of the ERBB family as EGFR (Yarden, Sliwkowski, 2001). ERBB2 amplication and mutations are found in 1-3\% and $2-4 \%$ of NSCLC patients, respectively (Suh et al., 2016; Li et al., 2016). In ERBB2 aberration, exon 20 insertions could benefit from targeted therapies. Targeted therapeutic drugs such as Afatinib (EGFR inhibitor) and/or Neratinib (ERBB2 inhibitor) have been used for the effective treatment of NSCLC patients with indicated ERBB2 mutation (Table 1).

Table 1. Personalized medicine with targeted therapeutic drugs for effective treatment of NSCLC patients harboring targetable profile

\begin{tabular}{|c|c|c|c|}
\hline $\begin{array}{l}\text { Oncogenic } \\
\text { drivers }\end{array}$ & $\begin{array}{c}\text { Types of } \\
\text { Mutation/Rearrangement }\end{array}$ & Mutations/Fusions & $\begin{array}{c}\text { Targeted therapy } \\
\text { drugs }\end{array}$ \\
\hline \multirow{12}{*}{ EGFR } & \multirow{10}{*}{ Missense mutation } & G719A & \multirow{12}{*}{$\begin{array}{c}\text { Erlotinib } \\
\text { Gefitinib } \\
\text { Afatinib } \\
\text { Dacomitinib } \\
\text { Osimertinib }\end{array}$} \\
\hline & & G719S & \\
\hline & & G719C & \\
\hline & & G719D & \\
\hline & & S768I & \\
\hline & & T790M & \\
\hline & & C797S & \\
\hline & & L858R & \\
\hline & & L861Q & \\
\hline & & L861R & \\
\hline & \multirow{2}{*}{ Exon 19 deletion mutation } & K745_A750delinsK & \\
\hline & & K745_T751delinsKI & \\
\hline
\end{tabular}




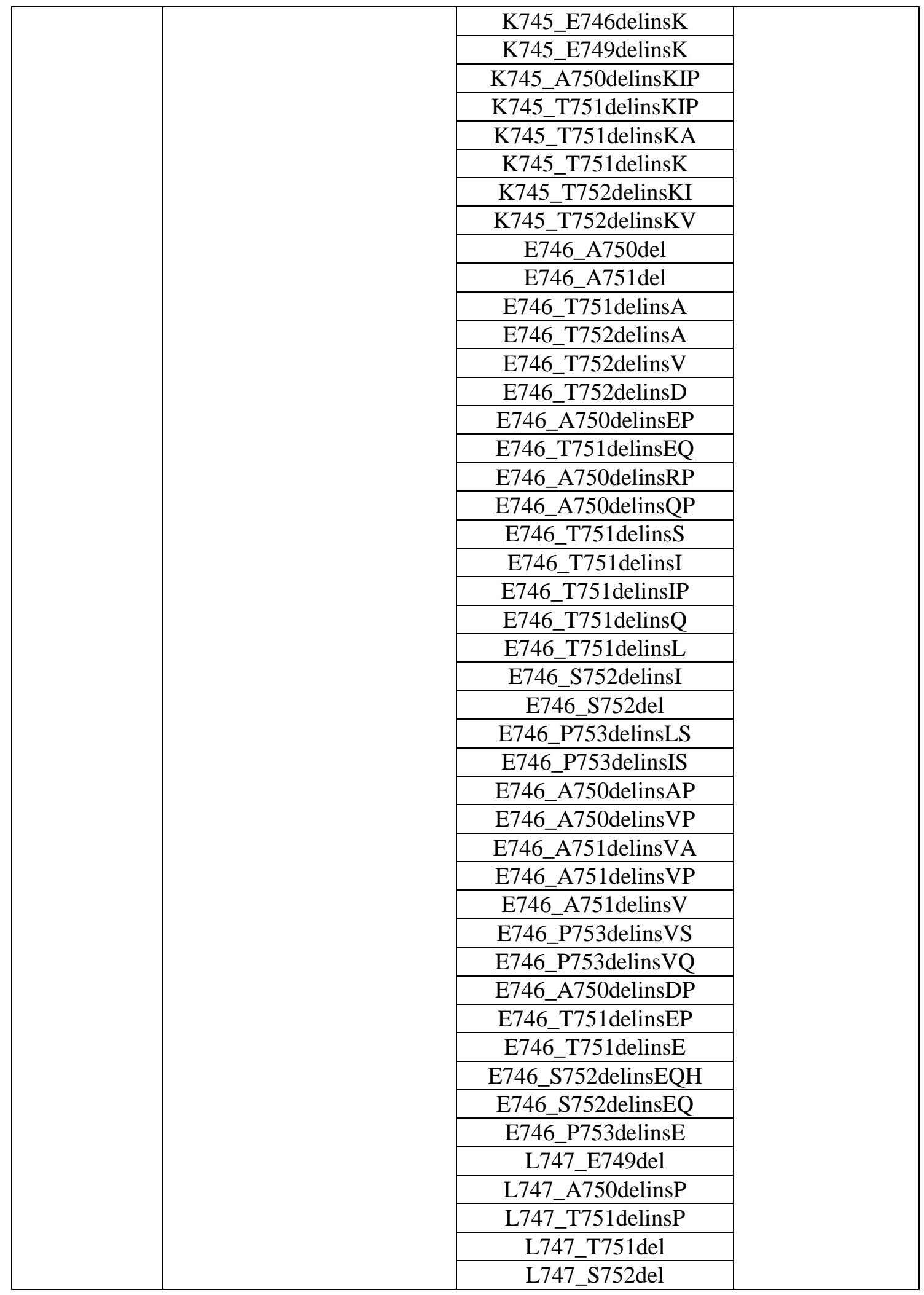




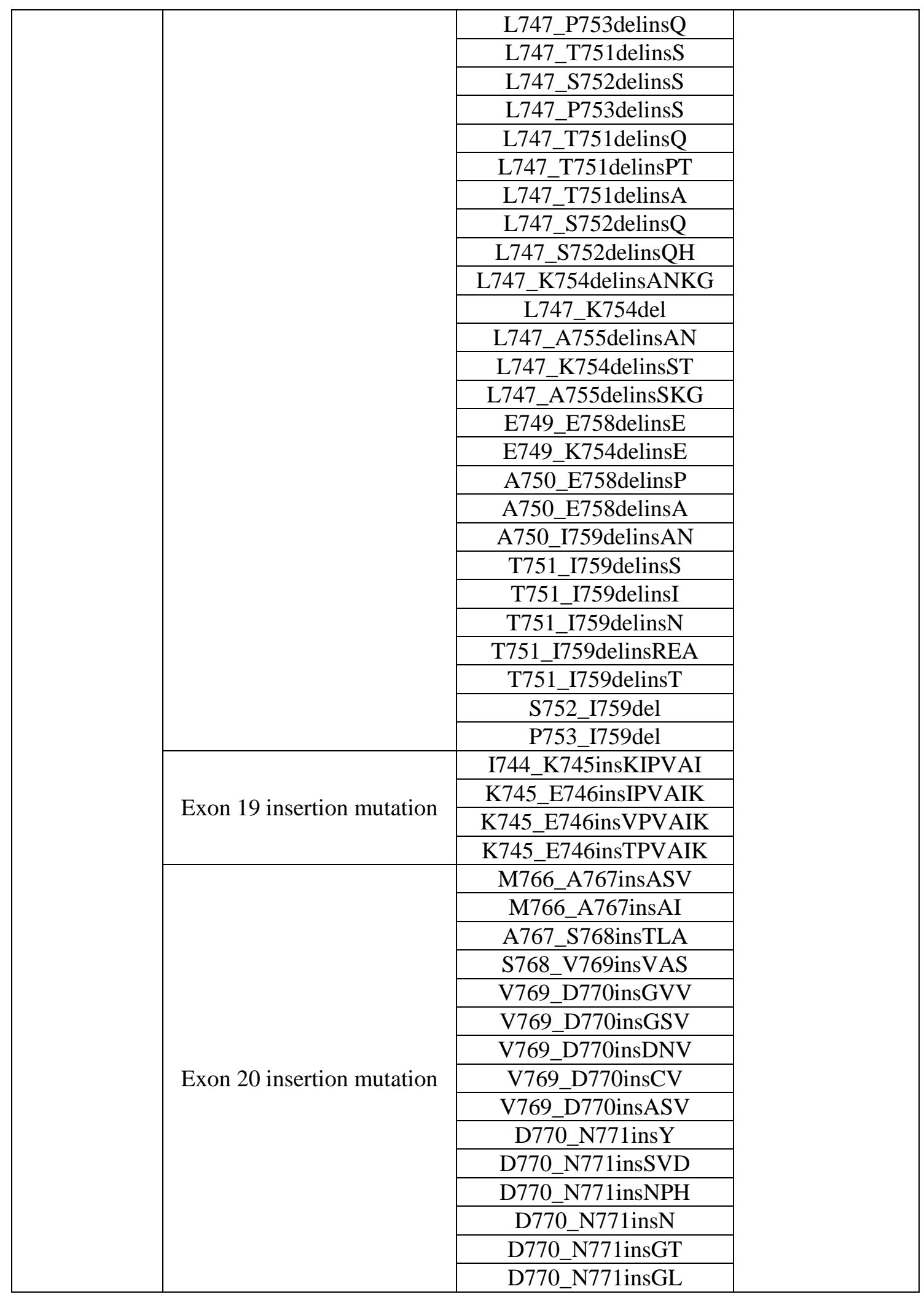




\begin{tabular}{|c|c|c|c|}
\hline & & D770_N771insGF & \\
\hline & & D770_N771insGD & \\
\hline & & D770_N771insG & \\
\hline & & D770_N771insAPW & \\
\hline & & N771delinsTH & \\
\hline & & N771delinsSH & \\
\hline & & N771delinsSGH & \\
\hline & & N771_P772insRH & \\
\hline & & N771_P772insN & \\
\hline & & N771_P772insH & \\
\hline & & P772_H773insV & \\
\hline & & P772_H773insTHP & \\
\hline & & P772_H773insHV & \\
\hline & & H773_V774insQ & \\
\hline & & H773_V774insPH & \\
\hline & & H773_V774insNPH & \\
\hline & & H773_V774insH & \\
\hline & & H773_V774insAH & \\
\hline & & V774_C775insHV & \\
\hline \multirow{23}{*}{ ALK } & \multirow{11}{*}{ Rearrangement } & EML4-ALK & \multirow{23}{*}{$\begin{array}{c}\text { Crizotinib } \\
\text { Ceritinib } \\
\text { Alectinib } \\
\text { Lorlatinib }\end{array}$} \\
\hline & & KIF5B-ALK & \\
\hline & & KLC1-ALK & \\
\hline & & HIP1-ALK & \\
\hline & & BIRC6-ALK & \\
\hline & & PRKAR1A-ALK & \\
\hline & & PPM1B-ALK & \\
\hline & & EIF2AK3-ALK & \\
\hline & & BCL11A-ALK & \\
\hline & & CEBPZ-ALK & \\
\hline & & PICAM-ALK & \\
\hline & \multirow{12}{*}{ Missense mutation } & 1151Tins & \\
\hline & & L1152R & \\
\hline & & $\mathrm{C} 1156 \mathrm{Y}$ & \\
\hline & & F1174L & \\
\hline & & L1196M & \\
\hline & & L1198F & \\
\hline & & G1202R & \\
\hline & & S1206Y & \\
\hline & & G1269A & \\
\hline & & $\mathrm{I} 1171 \mathrm{~T}$ & \\
\hline & & D1203N & \\
\hline & & V1180L & \\
\hline \multirow{3}{*}{ ROS1 } & \multirow{3}{*}{ Rearrangement } & CD74-ROS1 & \multirow{3}{*}{ Crizotinib } \\
\hline & & SDC4-ROS1 & \\
\hline & & SLC34A2-ROS1 & \\
\hline
\end{tabular}




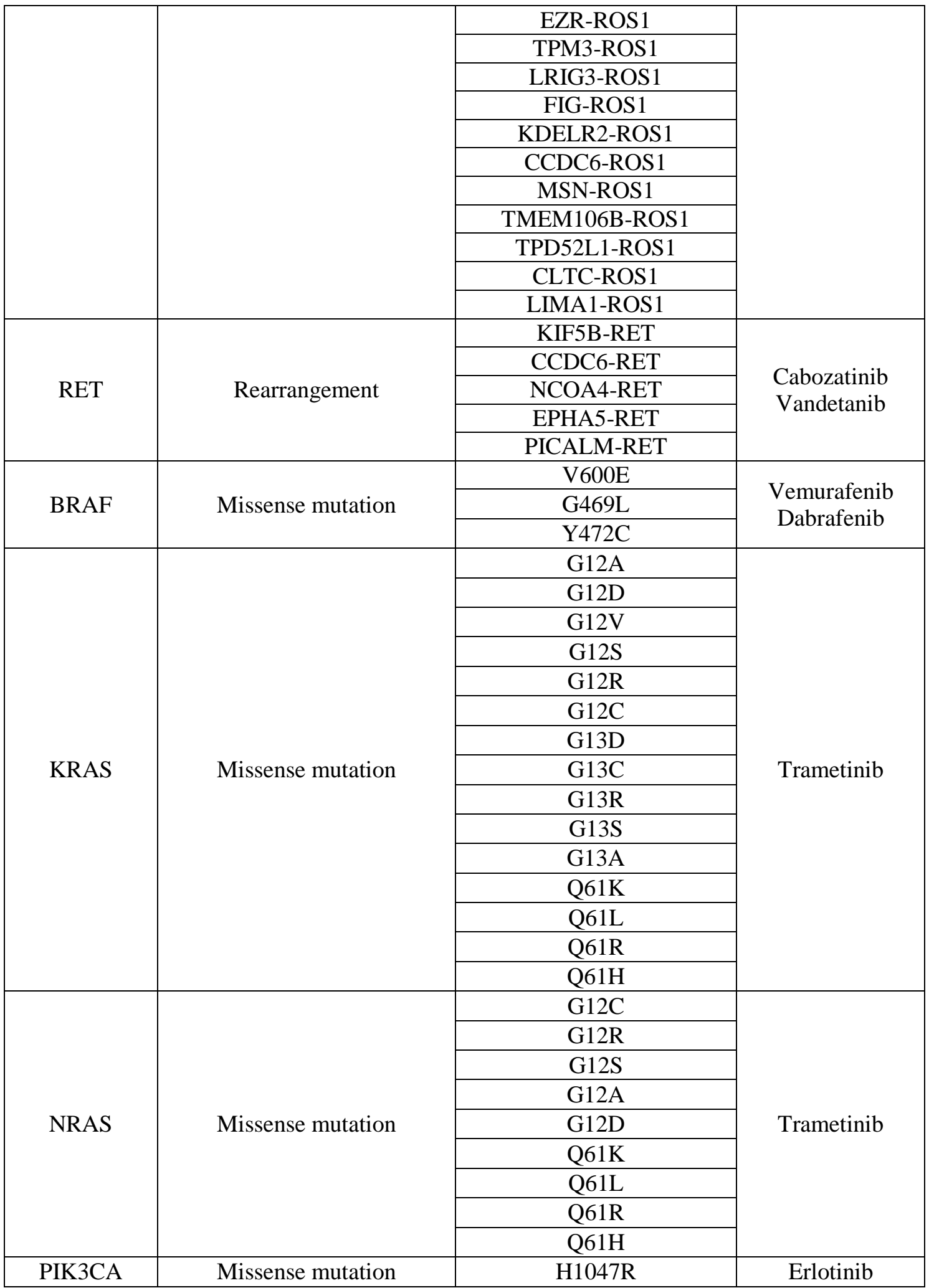




\begin{tabular}{|c|c|c|c|}
\hline & & H1047L & Gefitinib \\
\hline DDR2 & Missense mutation & S768R & Dasatinib \\
\hline \multirow{9}{*}{ MET } & \multirow{9}{*}{ Exon 14 skipping mutation } & c.2888-18_2888-7del12 & \multirow{9}{*}{$\begin{array}{c}\text { Crizotinib } \\
\text { Capmatinib } \\
\text { Glesatinib }\end{array}$} \\
\hline & & c.3024_3028+7del12 & \\
\hline & & c.3001_3021del21 & \\
\hline & & c. $3028 \mathrm{G}>\mathrm{T}$ & \\
\hline & & c.2888delA & \\
\hline & & c. $3028 \mathrm{G}>\mathrm{A}$ & \\
\hline & & c. $3028 \mathrm{G}>\mathrm{C}$ & \\
\hline & & c. $3028+1 \mathrm{G}>\mathrm{T}$ & \\
\hline & & c.2888-29_2888-6del24 & \\
\hline \multirow{6}{*}{ ERBB2 } & \multirow{6}{*}{ Exon 20 insertion mutation } & G776delinsVC & \multirow{6}{*}{$\begin{array}{c}\text { Afatinib } \\
\text { Neratinib }\end{array}$} \\
\hline & & V777_G778insCG & \\
\hline & & G778_S779insG & \\
\hline & & S779_P780insVGS & \\
\hline & & P780_Y781insGSP & \\
\hline & & G776Lfs*98 & \\
\hline
\end{tabular}

\section{CONCLUSION PERSPECTIVES}

Personalized medicine for effective treatment of NSCLC patients with EGFR mutations, ALK rearrangements and/or mutations, ROS1 rearrangements, RET rearrangements, BRAF mutations, KRAS mutations, NRAS mutations, PIK3CA mutations, DDR2 mutations, MET mutations and ERBB2 mutations has become the international standard of care for NSCLC patients (Fig. 1, Table 1). However, standardization and validation of detection methods for oncogenic drivers in NSCLC patients is very essential for accurate and reproducible results. Next-generation sequencing (NGS), a powerful detection method, will offer the vision of personalized medicine where an individual's treatment can be based on that patient's individual molecular profile, rather than on historical population-based medicine. NGS will be also the powerful method to identify new biomarkers for early diagnosis of lung cancer and is increasingly used to guide personalized treatments decisions for NSCLC patients.

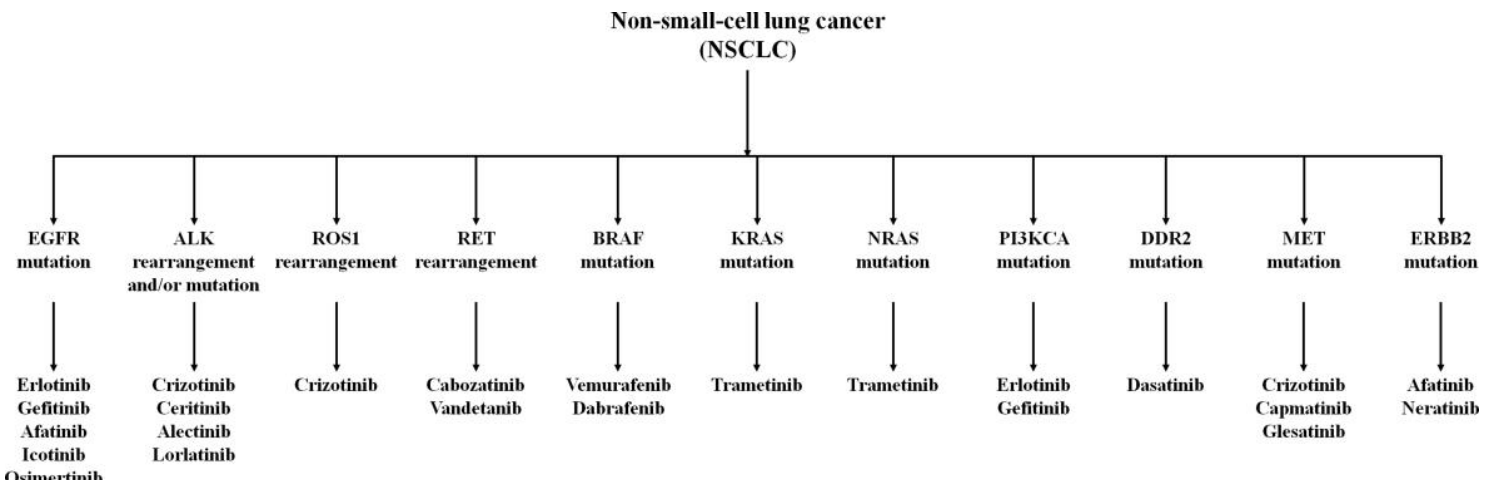

Figure 1. Personalized medicine with targeted therapeutic drugs for effective treatment of NSCLC patients harboring targetable profile 


\section{REFERENCES}

Aviel-Ronen S., Blackhall F. H., Shepherd F. A., Tsao M. S., 2006. K-ras mutations in non-small-cell lung carcinoma: a review. Clin. Lung. Cancer., 8(1): 30-38.

Bergethon K., Shaw A. T., Ou S. H., Katayama R., Lovely C. M., McDonald N. T., Massion P. P., Siwak-Tapp C., Gonzalez A., Fang R., Mark E. J., Batten J. M., Chen H., Wilner K. D., Kwak E. L., Clark J. W., Carbone D. P., Ji H., Engelman J. A., Mino-Kenudson M., Pao W., Lafrate A. J., 2012. ROS1 rearrangements define a unique molecular class of lung cancers. J. Clin Oncol., 30(8): 863-870.

Bray F., Ferlay J., Soerjomataram I., Siegel R. L., Torre L. A., Jemal A., 2018. Global caner statistics 2018: GLOBOCAN estimates of incidence and mortality worldwide for 36 cancers in 185 countries. CA. Cancer. J. Clin., 68(6): 394-424.

Camidge D. R., Kono S. A., Flacco A., Tan A.C., Doebele R.C., Zhou Q., Crino L., Franklin W.A., Varella-Garcia M., 2010. Optimizing the detection of lung cancer patients harboring anaplastic lymphoma kinase (ALK) gene rearrangements potentially suitable for ALK inhibitor treatment. Clin. Cancer. Res., 16(22): 5581-5590.

Cardarella S., Ogino A., Nishino M., Butaney M., Shen J., Lydon C., Yeap B. Y., Sholl L. M., Johnson B.E., Jänne P. A., 2013. Clinical, pathologic and biologic features associated with BRAF mutations in nonsmall cell lung cancer. Clin. Cancer. Res., 19(16): 4532-4540.

Chong C. R and Jänne P. A., 2013. The quest to overcome resistance to EGFR-targeted therapies in cancer. Nat. Med., 19(11): 1389-1400.

Du X., Shao Y., Qin H. F., Tai Y. H., Gao H. J., 2018. ALK-rearrangment in non-smallcell lung cancer (NSCLC). Thorar. Cancer., 9(4): 423-430.
Gainor J. F and Shaw A. T., 2013. Novel targets in non-small cell lung cancer: ROS1 and RET fusions. Oncologist., 18(7): 865-975.

Gainor J. F., Varghese A. M., Ou S. H., Kabraji S., Awad M. M., Katayama R., Pawlak A., Mino-Kenudson M., Yeap B. Y., Riely G. J., Iafrate A. J., Arcila M. E., Ladanyi M, Engelman J. A., DiasSantagata D and Shaw A. T., 2013. ALK rearrangements are mutually exclusive with mutations in EGFR or KRAS: an analysis of 1,683 patients with non-small cell lung cancer. Clin. Cancer. Res., 19(15): 4273-4281.

Gautschi O., Milia J., Filleron T., Wolf J., Carbone D. P., Owen D., Camidge R., Narayanan V., Doebele R. C., Besse B., Remon-Masip J., Janne P. A., Awad M. M., Peled N., Byoung C. C., Karp D. D., Van Den Heuvel M., Wakelee H.A., Neal J. W., Mok T. S. K., Yang J. C. H., Ou S. I., Pall G., Froesch P., Zalcman G., Gandara D. G., Riess J. W., Velcheti V., Zeidler K., Diebold J., Früh M., Michels S., Monnet I., Popat S., Rosell R., Karachaliou N., Rothschild S. I, Shih J. Y., 2017. Targeting RET in patients with RET-rearranged lung cancers: Results from the global, multicenter RET registry. J. Clin. Oncol., 35(13): 1403-1410.

Gridelli C., Rossi A., Carbone D. P., Guarize J., Karachaliou N., Mok T., Petrella F, Spaggiari L., Rosell R., 2015. Non-smallcell lung cancer. Nat. Rev. Dis. Primers., 1: 15009.

Guo Y., Cao R., Zhang X., Huang L., Sun L., Zhao J., Ma J., Han C., 2019. Recent progress in rare oncogenic drivers and targeted therapy for non-small cell lung cancer. Onco. Targets. Ther., 12: 10343-10360.

Horn L and Pao W., 2009. EML4-ALK: honing in on a new target in non-smallcell lung cancer. J. Clin. Oncol., 27(26): 4232-4235.

Inamura K., Takeuchi K., Togashi Y., Nomura K., Ninomiya H., Okui M., Satoh 
Y., Okumura S., Nakagama K., Soda M., Choi Y. L., Niki T., Mano H., Ishikawa Y., 2008. EML4-ALK fusion is linked to histological characteristics in a subset of lung cancers. J. Thorac. Oncol., 3(1): 13-17.

Katayama, 2017. Therapeutic strategies and mechanisms of drug resistance in anaplastic lymphoma kinase (ALK)rearranged lung cancer. Pharmacol. Ther., 177: 1-8.

Kohno T., Ichikawa H., Totoki Y., Yasuda K., Hiramoto M., Nammo T., Sakamoto H., Tsuta K., Furuta K., Shimada Y., Iwakawa R., Ogiwara H., Oike T., Enari M., Schetter A. J., Okayama H., Haugen A., Skaug V., Chiku S., Yamanaka I., Arai Y., Watanabe S., Sekine I., Ogawa S., Harris C. C., Tsuda H., Yoshida T., Yokota J., Shibata T., 2012. KIF5B-RET fusions in lung adenocarcinoma. Nat. Med., 18(3): 375-377.

Labrador J. P., Azcoitia V., Tuckermann J., Lin C., Olaso E., Manes S., Brückner K., Goergen J. L., Lemke G., Yancopoulos G., Angel P., Martinez C., Klein R., 2001. The collagen receptor DDR2 regulates proliferation and its elimination leads to dwarfism. EMBO. Rep., 2(5): 446-452.

Li B. T., Ross D. S., Aisner D. L., Chaft J. E., Hsu M., Kako S. L., Kris M. G., VarellaGarcia M., Arcila M. E., 2016. HER2 amplication and HER2 mutation are distinct molecular targets in lung cancers. J. Thorac. Oncol., 11(3): 414-419.

Li D., Ambrogio L., Shimamura T., Kubo S., Takahashi M., Chirieac L. R., Padera R. F., Shapiro G. I., Baum A., Himmelsbach F., Rettig W. J., Meyerson M., Solca F., Breulich H., Wong K. K., 2008. BIBW2992, an irreversibla EGFR/HER2 inhibitor highly effective in preclinical lung cancer models. Oncogene., 27(34): 4702-4711.

Li T., Kung H. J., Mack P. C., Gandara D. R., 2013. Genotyping and genomic profiling of non-small-cell lung cancer: Implications for current and future therapies. J. Clin. Oncol., 31(8): 1039-1049.

Lin J. J. and Shaw A. T., 2017. Recent advances in targeting ROS1 in lung cancer. J. Thorac Oncol., 12(11): 1611-1625.

Lin J. J., Kennedy E., Sequist L. V., Brastianos P. K., Goodwin K. E., Stevens S., Wanat A. C., Stober L. L., Digumarthy S. R., Engelman J. A., Shaw A. T., Gainor J. F., 2016. Clinical activity of Alectinib in advanced RET-rearranged non-small cell lung cancer. J. Thorac. Oncol., 11(11): 2027-2032.

Lin J. J., Riely G. J., Shaw A. T., 2017. Targeting ALK: precision medicine takes on drug resistance. Cancer. Discov., 7(2): $137-155$.

Marchetti A., Felicioni L., Malatesta S., Grazia Sciarrotta M., Guetti L., Chella A., Viola P., Pullara C., Mucilli F., Buttitta F., 2011. Clinical features and outcome of patients with non-small-cell lung cancer harboring BRAF mutations. J. Clin. Oncol., 29(26): 3574-3579.

Mazières J., Zalcman G., Crinò L., Biondani P., Barlesi F., Filleron T., Dingemans A. M., Léna H., Monnet I., Rothschild S. I., Cappuzzo F., Besse B., Thiberville L., Rouvière D., Dziadziuszko R., Smit E. F., Wolf J., Spirig C., Pecuchet N., Leenders F., Heuckman J. M., Diebold J., Milia J. D., Thomas R. K., Gautschi O., 2015. Crizotinib therapy for advanced lung adenocarcinoma and a ROS1 rearrangement: results from the EUROS1 cohort. J. Clin. Oncol., 33(9): 992-999.

Mok T. S., Wu Y. L., Ahn M. J., Garassino M. C., Kim H. R., Ramalingam S. S., Shepherd F. A., He Y., Akamatsu H., Theelen W. S., Lee C. K., Sebastian M., Templeton A., Mann H., Marotti M., Ghiorghiu S., Papadimitrakopoulou V. A., AURA3 investigators, 2017. Osimertinib or platinum-pemetrexed in EGFR T790M positive lung cancer. N. Engl. J. Med., 376(7): 629-640. 
O'Leary C. G., Andelkovic V., Ladwa R., Pavlakis N., Zhou C., Hirsch F., Richard D., ÓByrne K., 2019. Targeting BRAF mutations in no-small cell lung cancer. Transl. Lung. Cancer. Res., 8(6): 1119-1124.

Ohashi K., Sequist L. V., Arcila M. E., Lovly C. M., Chen X., Rudin C. M., Moran T., Camidge D. R, Vnencak-Jones C.L., Berry L., Pan Y., Sakaki H., Engelman J. A., Garon E. B., Dubinett S. M., Franklin W. A., Riely G. J., Sos M. L., Kris M. G., Dias-Santagata D., Ladanyi M., Bunn P. A Jr., Pao W., 2013. Characteristics of lung cancers harboring NRAS mutations. Clin. Cancer. Res.. 19(9): 2584-2591.

Pfister D. G., Johson D. H., Azzoli C. G., Sause W., Smith T. J., Baker S., Olak J., Stover D., Strawn J. R., Turrisi A. T., Somerfield M. R., 2004. American Society of Clinical Oncology treatment of unresectable non-small-cell lung cancer guideline: Updated 2003. J. Clin. Oncol., 22: $330-353$.

Reungwetwattana T and Dy G. K., 2013. Targeted therapies in development for non-small cell lung cancer. J. Carcinog., 12: 22 .

Rikova K., Guo A., Zeng Q., Possemato A., Yu J., Haack H., Nardone J., Lee K., Reeves C., Li Y., Hu Y., Tan Z., Stokes M., Sullivan L., Mitchell J., Wetzel R., Macneill J., Ren J. M., Yuan J., Bakalarski C.E., Villen J., Kornhauser J. M., Smith B., Li D., Zhou X., Gygi S. P., Gu T. L., Polakiewicz R. D., Rush J., Comb M. J., 2007. Global survey of phosphatyrosine signaling identifies oncogenic kinases in lung cancer. Cell., 131(6): 1190-1203.

Rosas G., Ruiz R., Araujo J. M., Pinto J. A., Mas L., 2019. ALK rearrangements: Biology, detection and opportunities of therapy in non-small cell lung cancer. Crit. Rev. Oncol. Hematol., 136: 48-55.

Sarfaty M., Moore A., Neiman V., Dudnik E., Ilouze M., Gottfriend M., Katznelson R.,
Nechushtan H., Sorotsky H. G., Paz K., Katz A., Saute M., Wolner M., Moskovitz M., Miller V., Elvin J., Lipson D., Ali S., Gutman L. S., Dvir A., Gordon N., Peled N., 2017. RET fusion lung carcinoma: Response to therapy and clinical features in a case series of 14 patients. Clin. Lung. Cancer., 18(4): e223-e232.

Sharma S. V., Bell D. W., Settleman J., Haber D. A., 2007. Epidermal growth factor receptor mutations in lung cancer. Nat. Rev. Cancer., 7(3): 169-181.

Shaw A. T., Gandhi L., Gadgeel S., Riely G. J., Cetnar J., West H., Camidge D. R., Socinski M. A., Chiappori A., Mekhail T., Chao B. H., Borghaei H., Gold K. A., Zeater A., Bordogna W., Balas B., Puig O., Henschel V., Ou S. I., Study investigators, 2016. Alectinib in ALKpositive, crizotinib-resistant, non-smallcell lung cancer: a single-group, multicentre, phase 2 trial. Lancet. Oncol., 17(2): 234-242.

Shaw A. T, Kim D. W, Mehra R, Tan D. S., Felip E., Chow L. Q., Camidge D. R., Vansteenkiste J., Sharma S., De Pas T., Riely G. J., Solomon B. J., Wolf J., Thomas M., Schuler M., Liu U., Santoro A, Lau Y. Y., Goldwasser M., Boral A. L., Engelman J. A., 2014. Ceritinib in ALKrearranged non-small-cell lung cancer. $N$. Engl. J. Med., 370(13): 1189-1197.

Shaw A. T., Kim D. W., Nakagawa K., Seto T., Crino L., Ahn M.J., De Pá T., Bese B., Solomon B.J., Blackhall F., Wu Y. L., Thomas M., ÓByrne K.J., Moro-Sibulot D., Camidge D. R., Mok T., Hirsh V., Riely G. J., Lyer S., Tassell V., Polli A., Wilner K. D., Jänne P. A., 2013. Crizotinib versus chemotherapy in advanced ALK-positive lung cancer. $N$. Engl. J. Med., 368(25): 2385-2394.

Shaw A. T., Ou S. H., Bang Y. J., Camidge D. R., Solomon B. J., Salgia R., Riely G. J., Varella-Garcia M., Shapiro G. I., Costa D. B., Doebele R. C., Le L. P., Zheng Z., Tan W., Stephenson P., Shreeve S. M., Tye L. 
M., Christensen J. G., Wilner K. D., Clark J. W., Lafrate A. J., 2014. Crizotinib in ROS1-rearranged non-small-cell lung cancer. N. Engl. J. Med., 371(21): 1963-1971.

Shaw A. T., Yeap B. Y., Mino-Kenudson M., Digumarthy S. R., Costa D. B., Heist R. S., Solomon B., Stubbs H., Admane S., MeDermott U., Settleman J., Kobayashi S., Mark E. J., Rodig S. J., Chirieac L. R., Kwak E. L., Lynch T. J., Lafrate A. J., 2009. Clinical features and outcome of patients with non-small-cell lung cancer who harbor EML4-ALK. J. Clin. Oncol., 27(26): 4247-4253.

Shi Y., Au J. S., Thongprasert S., Srinivasan S., Tsai C. M., Khoa M. T., Heeroma K., Itoh Y., Cornelio G., Yang P. C., 2014. A prospective, molecular epidemiology study of EGFR mutations in Asian patients with advanced non-small-cell lung cancer of adenocarcinoma histology (PIONEER). J. Thorar. Oncol., 9(2): 154-162.

Soda M., Choi Y. L., Enomoto M., Takada S., Yamashita Y., Ishikawa S., Fujiwara S., Watanabe H., Kurashina K., Hatanaka H., Bando M., Ohno S., Ishikawa Y., Aburatani H., Niki T., Sohara Y., Sugiyama Y., Mano H., 2007. Identification of the transforming EMLA4-ALK fusion gen in non-smallcell lung cancer. Nature., 448(7153): 561-566.

Solomon B. J., Mok T., Kim D. W., Wu Y. L., Nakagawa K., Mekhail T., Felip E., Cappuzzo F., Paolini J., Usari T., Lyer S., Reisman A., Wilner K. D., Tursi J., Blackhall F., PROFILE 1014 Investigators, 2014. First-line crizotinib versus chemotherapy in ALK-positive lung cancer. N. Engl. J. Med., 371(23): 2167-2177.

Suh J. H., Johnson A., Albacker L., Wang K., Chmielecki J., Frampton G., Gay L., Elvin J. A., Vergilio J. A., Ali S., Miller V. A.,
Stephens P. J., Ross J. S., 2016. Comprehensive genomic profiling facilitates implementation of the national comprehensive cancer network guidelines for lung cancer biomarker testing and identifies patients who may benefit from enrollment in mechanism-driven clinical trials. Oncologist., 21(6): 684-691.

Sun Y., Ren Y., Fang Z., Li C., Fang R., Gao B., Han X., Tian W., Pao W., Chen H., Ji H., 2010. Lung adenocarcinoma from East Asian never-smokers is a disease largely defined by targetable oncogenic mutant kinases. J. Clin. Oncol., 28(30): 4616-4620.

Takahashi M., Ritz J and Cooper G. M., 1985. Activation of a novel human transforming gene, ret, by DNA rearrangement. Cell., 42(2): 581-588.

Takeuchi K., Soda M., Togashi Y., Suzuki R., Sakata S., Hatano S., Asaka R., Hamanaka W., Ninomiya H., Uehara H., Lim Choi Y., Satoh Y., Okumura S., Nakagama K., Mano H., Ishikawa Y., 2012. RET, ROS1 and ALK fusions in lung cancer. Nat. Med., 18(3): 378-381.

Toyokawa G and Seto T., 2015. Updated evidence on the mechanisms of resistance to ALK inhibitor and strategies to overcome such resistance: Clinical and preclinical data. Oncol. Res. Treat., 38(6): 291-298.

Travis W. D., Brambilla E., Riely G. J., 2013. New pathologic classification of lung cancer: relevance for clinical practice and clinical trials. J. Clin. Oncol., 31(8): 992-1001.

Vogel W., Gish G. D., Alves F., Pawson T., 1997. The discoidin domain receptor tyrosine kinases are activated by collagen. Mol. Cell., 1(1): 13-23.

Vuong H. G., Ho A. T. N., Altibi A. M. A., Nakazawa T., Katoh R., Kondo T., 2018. Clinicalpathological implications of MET exon 14 mutations in non-small cell lung 
cancer - A systematic review and metaanalysis. Lung Cancer., 123: 76-82.

Walsh L. A., Nawshad A., Medici D., 2011. Discoidin domain receptor 2 is a critical regulator of epithemial-mesenchymal transition. Matrix. Biol., 30(4): 243-247.

Yarden Y and Sliwkowski M. X., 2001. Untangling the erbB signaling network. Nat. Rev. Mol. Cell. Biol., 2(2): 127-137.
Yoh K., Seto T., Satouchi M., Nishio M., Yamamoto N., Murakami H., Nogami N., Matsumoto S., Kohno T., Tsuta K., Tschihara K., Ishii G., Nomura S., Sato A., Ohtsu A., Ohe Y., Goto K., 2017. Vandetanib in patients with previously treated RET-rearranged advanced nonsmall-cell lung cancer (LURET): an openlabel, multicentre phase 2 trial. Lancet. Respir. Med., 5(1): 42-50. 